\title{
We Are Travellers: The Body as a Compass
}

\author{
Carolina Bergonzoni \\ Simon Fraser University
}

\begin{abstract}
This article introduces the practice of walking-as-dancing. In this article, the terms walk and walking are often considered as synonymous with wandering since the practice of walking-asdancing that I will describe does not have a set goal. When walking-as-dancing, I explore the improvisational nature of a wandering movement that allows me to let go of certainty and attune to the not-yet-known. I define the body as a compass that guides us through the path of the curriculum-as-lived (Aoki, 1993) and the curriculum itself. Through the analysis of the practice of walking-as-dancing, I will show how the knowledge of the body is already in us; it is us.
\end{abstract}

Keywords: walking-as-dancing; wandering; body as compass; body data; lived curriculum 


\section{Nous sommes voyageurs : le corps en tant que boussole}

\section{Résumé :}

Cet article présente la pratique de la marche en tant que la danse. Dans cet article, les termes « la marche » et «marcher» se considèrent souvent comme synonymes de flâner car la pratique de la marche en tant que la danse que je vais décrire n'a pas d'objectif fixé. En marchant comme danser, j'explore la nature improvisée d'un mouvement baladant qui me permet de lâcher prise de certitude et de m'accorder avec l'inconnu. Je définis le corps comme une boussole qui nous guide à travers le chemin du curriculum comme vécu (Aoki, 1993) et le curriculum lui-même. À travers l'analyse de la pratique de la marche-comme-danse, je montrerai comment la connaissance du corps est déjà en nous; c'est nous nous-mêmes.

Mots clés : marcher comme danser; flâner; le corps comme boussole; les données corporelles; le curriculum vécu 
Tr Italian, my first language, "to wander" and "to err" both translate to the same word: errare. To wander underlines the pleasure of travelling toward the known and the unknown, without a clear direction. In this article, I will use the terms walk and walking as synonymous with wandering since the practice that I describe does not have a set goal. Further, I extend walking to include dancing, in what I define as walking-as-dancing. I will explore and illustrate the improvisational nature of a wandering movement that allows me to let go of certainty and attune to the not-yet-known.

From a very young age, I have been in a relationship with the inner landscape of my body and perceived it as the lived curriculum (Aoki, 1993). When discussing the connection between walking and pedagogy, we cannot forget the groundwork of educator William F. Pinar, who has established that the word "curriculum" comes from the Latin currere, meaning to run the course. For Pinar (1994), currere is a way to look at the relationships with our identities, our presents, pasts and futures; it is a way to explore our own relation "to the Self and its evolution and education" (Pinar, 1994, p. 19). Rita Irwin (2006) reframes currere as "walking the course" (p. 77), rather than rushing through it.

My body is not only the possibility of walking the course, my body is the course itself. Currere, then, just like walking, is a term that implies dynamic movement, and this movement is often relational. When we walk, we are never alone: we walk in relationship with/in the environment; we walk with concepts, writers and readings; we walk with our teachers and students; and we walk with ourselves.

Over the years, I developed a practice of walking-as-dancing, an improvisational practice and a living pedagogical inquiry through which we can re/discover our relationships. This practice is influenced by arts-based research approaches and is particularly rooted in embodied inquiry (Snowber 2002; Snowber, 2014; Snowber, 2016). As a dance artist, educator and full-bodied researcher-a term I use to indicate the prominent role of the wholeness of the body in all aspects of my research-I believe that our bodies are sites of knowledge, and that the knowledge of the body is already in us; it is us.

The practice of walking-as-dancing allows us to re/connect to ourselves, to the Earth and to other living beings. A walk-as-dance looks just like a functional walk, but there is a shift in the intention and the "self-awareness so that the walk becomes an explicitly expressive dance" (Bergonzoni, 2017, p. 35). In a walk-as-dance, we can focus on noticing our senses, our environment, and other humans and non-human subjects, so that we are more open to the possibility of finding wonder in the everyday.

When training as a dancer, I learned how to feel, connect and to get in touch with my body. Dance taught me how to be in my body and my body taught me who I am. If we consider the body as a compass - as from the Latin meaning of compass as "to step with" (Oxford English Dictionary)our bodies help us navigate the world and orient us toward objects and other living beings in spatial relations of proximity and distance (Ahmed, 2006). The body as a compass helps us negotiate space at the grocery store, fit into spaces, become bigger or smaller depending on the situation, since 
"some spaces extend certain bodies and simply do not leave room for others" (Ahmed, 2006, p. 11). For instance, when my body navigates public space, such as city transit, I negotiate the adjustments that become necessary to finding a place to fit by taking up as little space as possible. The conditions of space are relative to the moment when I enter and engage. The body "knows where our mind may not be able to lead us" (Snowber, 2007, p. 1452) and guides us where we thought we couldn't go.

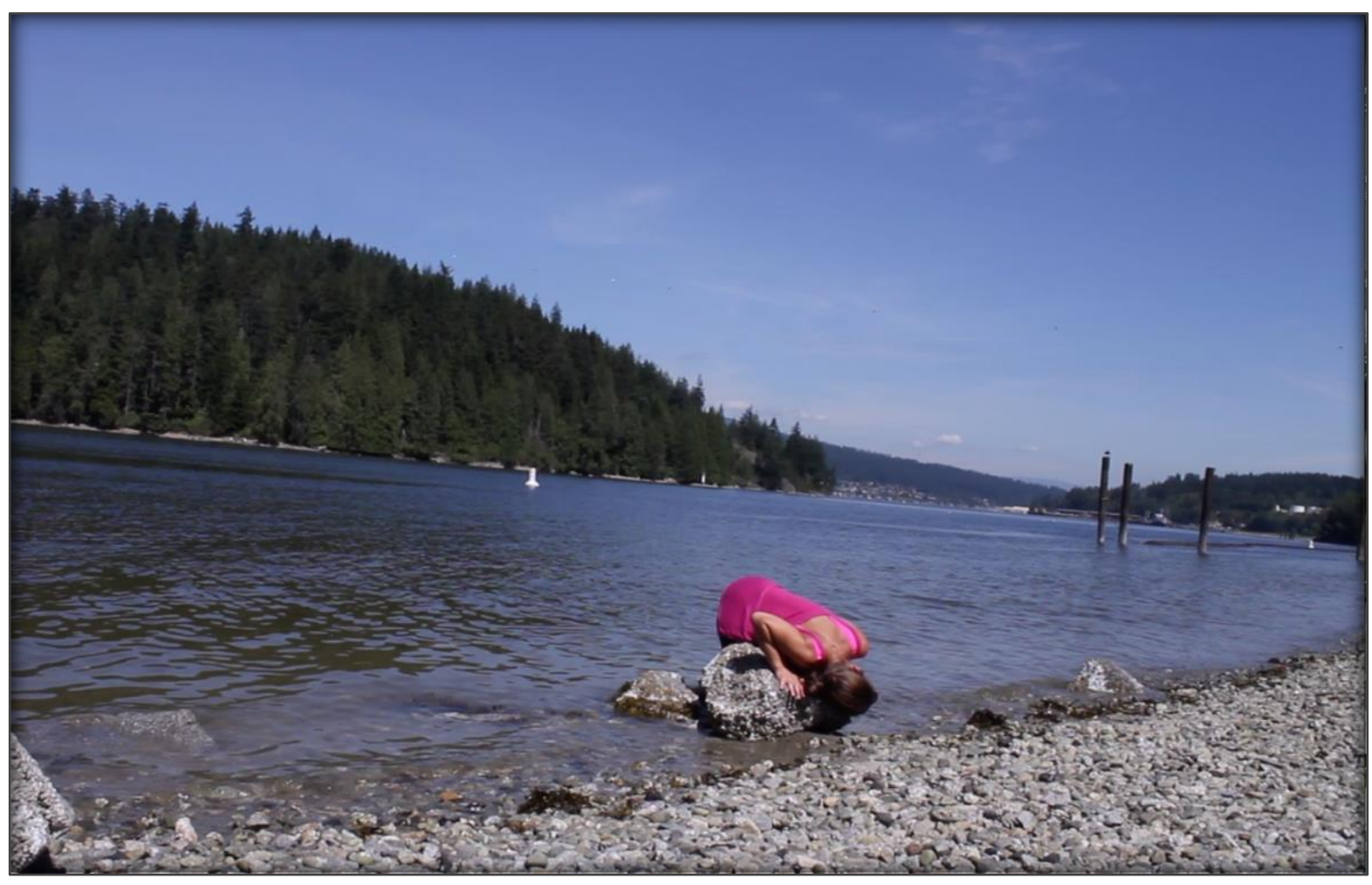

Becoming Rocks. Photo credit: C. Bergonzoni, 2020.

I walk in the sand.

At each step

the land morphs for me.

My body reverberates the way waves do.

Each step,

a spiral comes back.

It is a language

that changes what it encounters,

while being shaped by it.

I become water,

I become rocks, 
in a body of water.

It is a walk of the salty and sandy feet.

It is grounded in the Earth

yet, it floats like the Ocean.

A flow of thoughts.

When I started graduate school, I no longer had time for daily dance classes and my dance practice shifted drastically; as a result, I began dancing my walks (Bergonzoni, 2017). Although I did not have time for dance classes, I was able to find time for my walks. My walks became a place to explore some of the improvisation principles that I would have explored in the dance studio.

Walking-as-dancing shares some of the core principles of dance improvisation: practicing patience and letting go of what is familiar, within set parameters, to allow for exploration. I walk and dance in an "interplay between intuition and structure", which "is central to the process of improvisation and to art-based research" (Sajnani, 2013, p. 81). I know where I am departing from, and I know I will eventually return home; however, the pathway might be unclear, unknown and totally improvised. The practice of walking-as-dancing creates a cyclical dance of moving in-between the known and the unknown.

Not only does walking increase creativity (Oppezzo \& Schwartz, 2014), but movement facilitates the flow of ideas through our bodies. Walking also influences the way we write; "the patterns of coordination and balance ... play a constitutive role in what one who walks can later write" (LaMothe, 2015, p. 70). On our path, each discovery creates new memories that get stored in our cells in a process that I think of as re-membraining. remembering in the membranes of our tissues, bones and muscles. Through walking, we allow for movement to flow and for unconsciously stored histories and memories to arise from our cells to the surface of our awareness through the flow of movement. Our bodies support the notion that "to walk on this earth is to walk on a living past, on the open pages of history and geology" (Hogan, 2007, p. 79).

The practice of walking-as-dancing requires that we constantly track body data (Snowber, 2002) and process them in real time to generate new data. Our porous bodies are living proof of the documentation of the research: they are the data and the reflection of the data. Our bodies draw their own topographies and, through movement, we become living and lived curriculum. This suggests that we learn about our environment, other subjects and ourselves. I think that when we walk-as-dancing, we follow the guidance of our body-compasses, and we unfold into the course. The body is not only the possibility of walking the course, the body becomes the course. The body is the curriculum-as-lived (Aoki, 1993, p. 257).

Through the practice of walking-as-dancing, I learned how to attune to the environment, bridging the inner landscape of my body and the landscapes of the outer world. The environment and its relationship to my body became my new teacher. By being open to the environment and to experiencing it, I learn new nuances of myself, of my surroundings and of my relationships with other bodies. During my solitary walks-as-dance, my dance partners became trees, sidewalks, bodies of 
water, industrial areas, urban landscapes and unaware pedestrians. I am often overwhelmed by the sensorial memories that arise: the smell of the flowers that reminds me of my grandmother's kitchen; the texture of the sand on my feet inviting me to move differently; the majesty of a tree reminding me to breathe and reconnect with my organs. This practice has made me deeply grateful and appreciative of what I already have: a body and an environment in which to play, explore and research within—to wander in wonder (Lyle \& Snowber, 2021).

When we wander, we improvise. There is no attachment to the pathway we take, the sensations and feelings that arise in our bodies and the emotions we experience. Even when we feel lost, we are still going somewhere, as "being lost is a way of inhabiting space by registering what is not familiar: being lost can in its turn become a familiar feeling" (Ahmed, 2006, p. 7). Each step is a possibility to let go of what we thought we knew and an opportunity to start over again. If we consider that "the unfamiliar often appears through curiosity" (Fraleigh, 2018, p. 18), the connection between wander and wonder becomes clear.

The practice of walking-as-dancing allows me to attune to the body, becoming more aware of the environment, myself and others. Walking-as-dancing shifts my perception and connects me with the tissues of my body, grounding and centering me. When I am full-bodied, meaning when I am fully connected with the wisdom of the body, I am also able to support students and connect with them on a much deeper level. Walking-as-dancing has become a vital part of my teaching practice, and it helps me to stay connected with my body, re-membraining my relations, and being fullbodied for the students with whom I interact. This enriching practice is rooted in the idea that the body is not only the compass to guide us through the lived curriculum (Aoki, 1993), but it is a living curriculum itself whose knowledge is already in us. We must attune to our bodies so that we can become open to the possibilities of wonder in the everyday.

\section{About the Author}

Originally from Italy, Carolina Bergonzoni is a dance artist and PhD candidate in the Arts Education program at Simon Fraser University. She is the recipient of a SSHRC Doctoral Fellowship and Dean's Entrance Graduate Scholarship. She is one of the editors-in-chief of SFU Educational Review. Her work has been published in international journals and presented at a wide variety of conferences and dance festivals. She serves as Artistic Associate of the dance company All Bodies Dance Project.

\section{References}

Ahmed, S. (2006). Queer phenomenology. Orientations, objects, other. Duke University Press.

Aoki, T. T. (1993), Legitimizing lived curriculum: Toward a curricular landscape of multiplicity. Journal of Curriculum and Supervision, 8(3), 255-268. http://proxy.lib.sfu.ca/login?url=https:// search.ebscohost.com/login.aspx?direct=true\&db=eue\&AN=9511050991\&site=ehost-live

Bergonzoni, C. (2017). When I dance my walk: A phenomenological analysis of habitual movement in dance practices. Phenomenology \& Practice, 11(1), 32-42. https://doi.org/10.29173/ pandpr29336 
Fraleigh, S. (2018). Phenomenology and life world. In S. Fraleigh (Ed.), Back to dance itself: Phenomenologies of the body in performance (pp. 11-26). University of Illinois Press.

Hogan, L. (2007). Dwellings: A spiritual history of the living world. Norton.

Irwin, R. L. (2006). Walking to create an aesthetic and spiritual currere. Visual Arts Research, 32(1), 75-82. https://www.jstor.org/stable/20715404.

LaMothe, K. L. (2015). Why we dance: A philosophy of bodily becoming. Columbia University Press.

Lyle, E., \& Snowber, C. (2021). Walking as attunement: Being with/in nature as currere. Journal of the Canadian Association for Curriculum Studies. https://jcacs.journals.yorku.ca/index.php/jcacs /issue/archive

Manning, E. (2009). Relationscapes: Movement, art, philosophy. MIT Press.

Oppezzo, M., \& Schwartz, D. L. (2014). Give your ideas some legs: The positive effect of walking on creative thinking. Journal of Experimental Psychology: Learning, Memory, and Cognition, 40(4), 1142-1152. http://dx.doi.org.proxy.lib.sfu.ca/10.1037/a0036577

Oxford English Dictionary. (1989). Compass. In Oxford English Dictionary (2 ${ }^{\text {nd }}$ ed.). www.oed.com /view/Entry/37466.

Pinar, W. (1994). The method of "currere". Counterpoints, 2, 19-27. http://www.jstor.org /stable/42975620

Sajnani, N. (2013). Improvisation and art-based research. In S. McNiff (Ed.), Art as research (pp. 77-84). Intellect.

Snowber, C. (2002). Bodydance: Enfleshing soulful inquiry through improvisation. In C. Bagley \& M. B. Cancienne (Eds.), Dancing the data (pp. 20-33). Peter Lang.

Snowber, C. (2007). The soul moves: Dance and spirituality in educative practice. In L. Bresler (Ed.), International handbook of research in arts education (pp. 1449-1456). Springer.

Snowber, C. (2014). Dancing on the breath of limbs: Embodied inquiry as a place of opening. In A. Williamson, G. Bateson, S. Whatley, \& R. Weber (Eds.), Dance, somatics, and spiritualities: Contemporary sacred narratives (pp. 115-130). University of Chicago Press.

Snowber, C. (2016). Embodied inquiry: Writing, living, and being through the body. Sense. 